DOI: 10.1002/adsc.201((will be filled in by the editorial staff))

\title{
Conversion of $\gamma$ - and $\delta$-Keto Esters into Optically Active Lactams. Transaminases in Cascade Processes
}

\author{
Ángela Mourelle-Insua, ${ }^{\mathrm{a}}$ Luiz Arthur Zampieri, ${ }^{\mathrm{a}, \mathrm{b}}$ Iván Lavandera ${ }^{\mathrm{a}, *}$ and Vicente Gotor- \\ Fernández, ${ }^{\mathrm{a}, *}$
}

a Organic and Inorganic Chemistry Department, Biotechnology Institute of Asturias (IUBA), University of Oviedo, Avenida Julián Clavería 8, 33006 Oviedo (Spain).

Corresponding authors: lavanderaivan@uniovi.es (Phone: +34 98 5103452); vicgotfer@uniovi.es (Phone: +34 98 5103454)

b Actual address: Organic and Inorganic Chemistry Department, Biotechnology and Natural Products Laboratory, Universidade Federal do Ceará, Campus do Pici, Fortaleza, Ceará 60455-970 (Brazil).

Received: ((will be filled in by the editorial staff))

Supporting information for this article is available on the WWW under http://dx.doi.org/10.1002/adsc.201\#\#\#\#\#\#. Extensive transaminase screenings, analytics, copies of HPLC chiral analyses, and ${ }^{1} \mathrm{H},{ }^{13} \mathrm{C}$ and DEPT NMR spectra for described organic compounds are included.

Dedicated to Prof. Vicente Gotor on occasion of his $70^{\text {th }}$ birthday

\begin{abstract}
A one-pot two-step enzymatic strategy has been designed for the production of optically active $\gamma$ - and $\delta$ lactams in aqueous medium under mild conditions. The approach is based on the biotransamination of ethyl or methyl keto esters bearing different alkyl or aryl substitution patterns at $\alpha$-position to the ketone functionality. In this manner, the keto esters were transformed into the corresponding amino esters with excellent conversions, which underwent spontaneous cyclisation in the reaction medium without addition of external reagents.
\end{abstract}

\section{Introduction}

Lactams are pivotal compounds in organic chemistry since they are present in numerous bioactive products, also serving as valuable intermediates for more complex structures including synthetic polymers. ${ }^{[1]}$ Apart from $\beta$-lactams (azetidin-2-ones, Figure 1) that constitute the most important class of currently approved antibiotics, ${ }^{[2]}$ the syntheses of $\gamma$-lactams (pyrrolidin-2-ones) and $\delta$-lactams (piperidin-2-ones) have attracted considerable attention in recent years, ${ }^{[3]}$ due to the presence of these nitrogen containing heterocycles in demanding biologically active compounds.

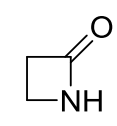

$\beta$-lactam

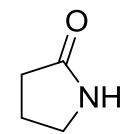

$\gamma$-lactam

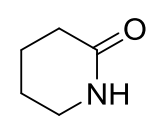

$\delta$-lactam
Figure 1. General structure of $\beta-, \gamma$ - and $\delta$-lactams.
Depending on the transaminase selectivity, both lactam enantiomers can be obtained, so initial enzyme screenings were performed using commercially available and made in house enzymes. Reaction conditions were optimised focusing on the substrate concentration, temperature and ratio of amine donor $v s$ acceptor. Thus, ten $\gamma$ - and $\delta$-lactams were obtained in good to high isolated yields $(70-90 \%)$ and excellent selectivities (94-99\%) after one or two days at 30 or $45^{\circ} \mathrm{C}$.

Keywords: Cascade reaction; Intramolecular cyclisation; Lactams; Stereoselective synthesis; Transaminase
Biocatalysis provides access to optically pure products under mild reaction conditions, including the stereoselective synthesis of lactams. ${ }^{[4]}$ Kinetic resolutions of racemic lactams via hydrolasecatalysed ring opening or $\mathrm{N}$-acylation reactions, have gained great attention in the last decades using lactamases, lipases or esterases. ${ }^{[5]}$ However, most of the examples are focused on the preparation of optically active $\beta$-lactams, and are limited to $50 \%$ yield due to the inherent limitations of classical kinetic resolutions.

Interestingly, lipases have served for the production of lactams through intramolecular cyclisation of carboxylic acid derivatives intermediates, although these approaches have been disclosed in a non-selective fashion. ${ }^{[6]}$ Transaminasecatalysed processes have also been reported for the production of lactams in a highly selective manner. ${ }^{[7]}$ This strategy is based on the biotransamination of aldo or keto esters and subsequent intramolecular 
cyclisation of the so-obtained optically active amino esters. In this manner, the chemical equilibrium is shifted to the formation of the desired lactams. In this scenario, the usefulness of commercially available transaminases has been reported for the conversion of ethyl 4-oxo-3-phenylbutyrate into $(R)-4$ phenylpyrrolidin-2-one, ${ }^{\{7 \mathrm{a}]}$ isopropyl 4-(4bromophenyl)-5-oxopentanoate into (S)-5-(4bromophenyl)piperidin-2-one, ${ }^{[7 \mathrm{c}]}$ and ethyl 4acetylbutyrate in both $(S)$ - and $(R)$-6-methylpiperidin2-one. ${ }^{[\mathrm{b}]}$ More recently a novel reductive aminase from Aspergillus oryzae has been engineered and applied in the reductive amination of ethyl levulinate using three aliphatic amines, allowing the asymmetric synthesis of optically active N-substituted lactams. ${ }^{[8]}$

Herein, we propose a general strategy for the asymmetric preparation of $\gamma$ - and $\delta$-lactams based on the biotransamination of easily accessible keto esters, followed by intramolecular cyclisation in the own reaction medium (Scheme 1). Screening and optimisation of the reaction conditions will be disclosed in order to give access to both enantiomers of a series of lactams in a one-pot two-step synthetic approach. The selection of the proper transaminase will be a key issue, affecting the reaction conditions such as $\mathrm{pH}$, substrate and amine donor concentrations and temperature, to develop high-yielding and stereoselective protocols.

\section{Results and Discussion}

Levulinic acid derivatives are considered valuable lactam precursors due to their simple preparation from lignocellulosic biomass and in some cases commercial availability. ${ }^{[9]}$ For that reason ethyl levulinate (1a) was selected as model substrate for this biotransamination screening. A $25 \mathrm{mM}$ substrate concentration was initially considered in order to test 26 commercial transaminases, all of them accepting isopropylamine (IPA) as amine donor. Initially, IPA was used in a large excess (1 M concentration), aiming to drive the equilibrium towards the formation of the amino ester $\mathbf{2 a}$, which will later spontaneously cyclise into the lactam $\mathbf{3 a}$.

For an exhaustive screening study, more data can be found in Table S3 in the Supporting Information. Based on previous studies, ${ }^{[10]} 2.5 \%$ of DMSO was used as cosolvent in combination with phosphate buffer $100 \mathrm{mM} \mathrm{pH}$ 7.5. The reactions were incubated for $24 \mathrm{~h}$ at $30{ }^{\circ} \mathrm{C}$, observing the solely formation of optically active 5-methylpyrrolidin-2-one (3a), obtained after spontaneous intramolecular cyclisation in the reaction medium of ethyl 4-aminopentanoate (2a). The best results have been summarised in Table 1 (entries 1-5), finding the best conditions for TA-P2B01 (87\% conversion, $>99 \%$ ee $(R)$, entry 2$)$ and ATA-237 (92\% conversion, $>99 \%$ ee $(S)$, entry 3$)$ in the complementary synthesis of both 3a lactam antipodes. In addition, transaminases such the $(S)$ selective ones from Chromobacterium violaceum $(\mathrm{Cv}-\mathrm{TA})^{[11]}$ and a variant from Arthrobacter citreus (ArS-TA) ${ }^{[12]}$ and the $(R)$-selective TAs from Arthrobacter species (ArR-TA) ${ }^{[13]}$ and an evolved mutant (ArRmut11-TA), ${ }^{[14]}$ were also tested as freeze-dried cell powder of $E$. coli containing the corresponding overexpressed enzyme. Particularly, an excellent activity and selectivity for ArS-TA was achieved towards the formation of $(S)-3 \mathbf{a}(97 \%$ conversion, $>99 \%$ ee, entry 5).

We also studied the effect of the leaving group, performing biotransamination experiments over methyl levulinate $(\mathbf{1 b}, \mathrm{R}=\mathrm{Me})$, which affords an alternative access to $\mathbf{3 a}$ (entries 6-11). Conversions over $80 \%$ were reached leading to both lactam enantiomers with excellent selectivity, finding a much higher reactivity for some enzymes such as TA-P2-A07 when considering the methyl instead of the ethyl ester as starting material (compare entries 1 and 6). For a full comparison of the transaminase activity between substrates $\mathbf{1 a}$ and $\mathbf{1 b}$, see Tables S3 and S4 in the Supporting Information. In summary, hits for both substrates 1a,b were found, although in general better conversions were achieved with the methyl keto ester derivative.

Looking for a further exploitation of the synthetic approach, the study of a substrate with an increased alkyl chain length between both carbonyl groups was considered. Thus, both enantiomers of $\delta$-lactam 6methylpiperidin-2-one were straightforward obtained from ethyl 5-oxohexanoate (3c) in a highly selective manner $(>88 \%$ conversion and $>96 \%$ ee $)$, using different enzymatic preparations (see entries 12-18 and also Tables S3 and S4 in the Supporting Information).
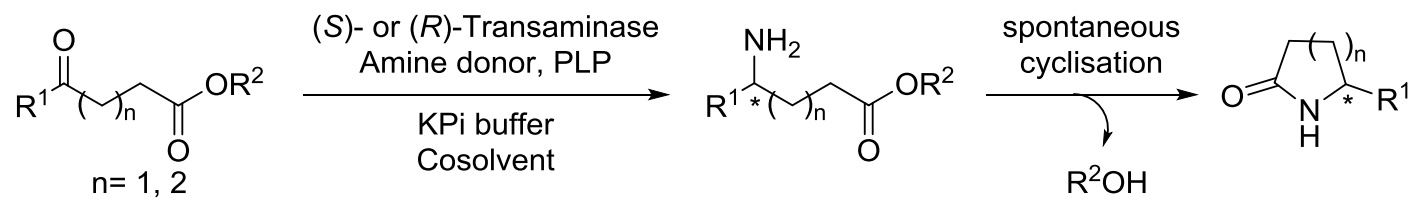

Scheme 1. General transformation of $\gamma$ - and $\delta$-keto esters into optically active lactams mediated by transaminases. 
Table 1. Stereoselective transformation of keto esters $1 \mathbf{a}-\mathbf{c}$ into lactams $\mathbf{3 a}$ and $\mathbf{3 c}$.

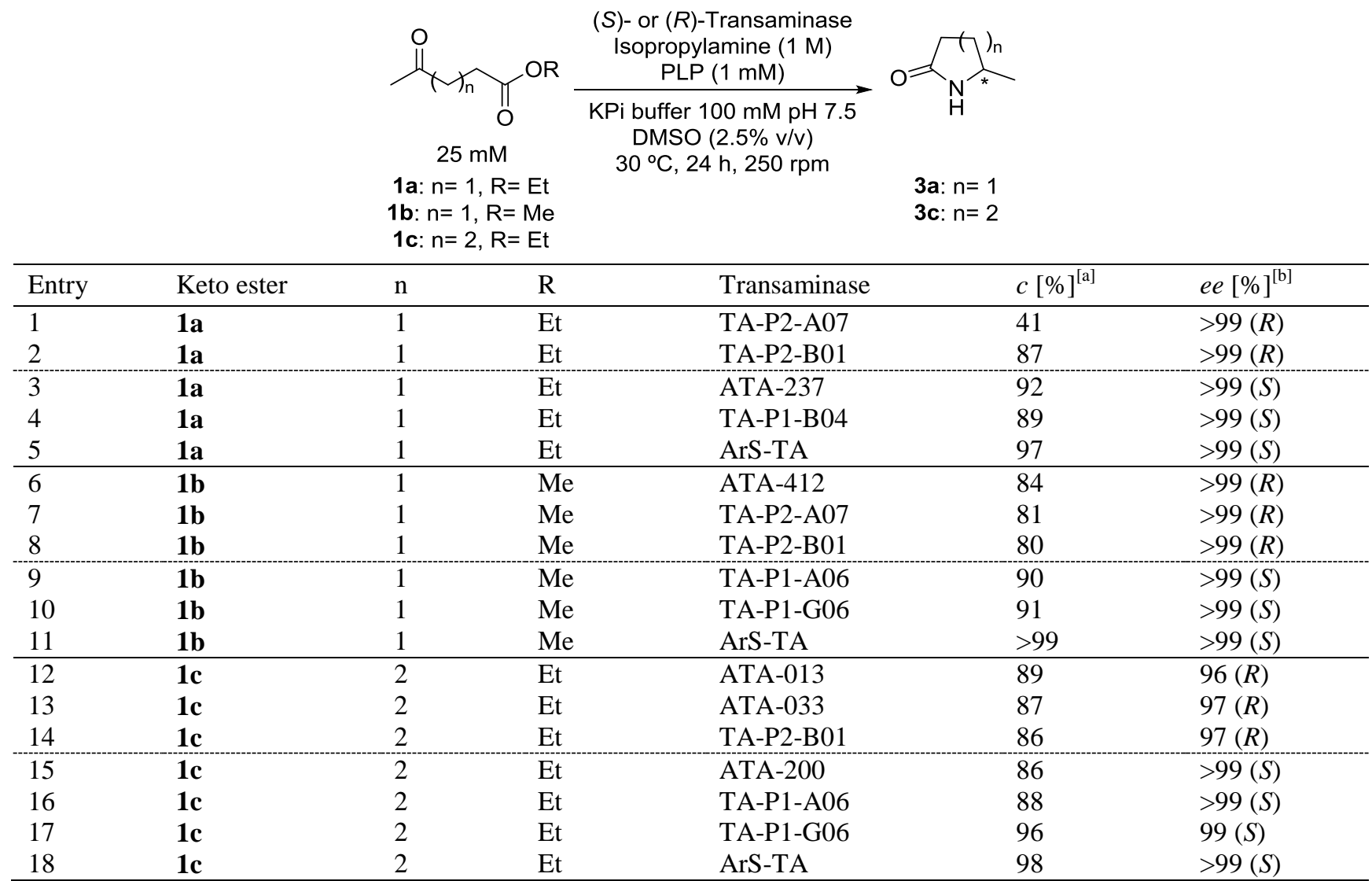

${ }^{[a]}$ Conversion values determined by GC (see Supporting Information). ${ }^{[b]}$ Determined by HPLC using chiral columns (see Supporting Information). Absolute configurations of the corresponding lactams 3a and 3c appear in brackets.

Table 2. Stereoselective transformation of $\gamma$-keto esters $\mathbf{1 d - h}$ into 5-arylpyrrolidin-2-ones $\mathbf{3 d - h}$.

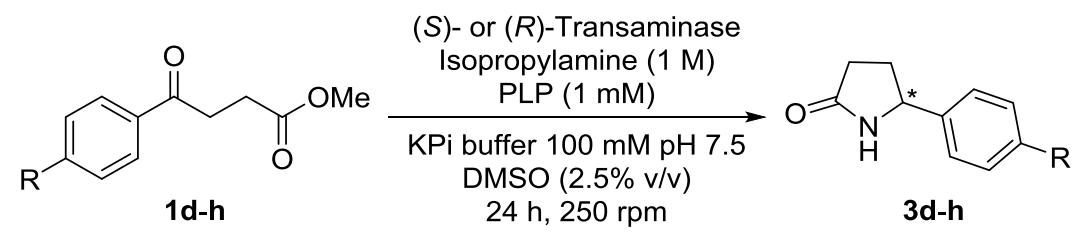

\begin{tabular}{|c|c|c|c|c|c|c|}
\hline Entry & $\mathrm{R}$ (Keto ester) & [Keto ester] $[\mathrm{mM}]$ & $\mathrm{T}\left[{ }^{\circ} \mathrm{C}\right]$ & Transaminase & $c[\%]^{[\mathrm{a}]}$ & $e e[\%]^{[\mathrm{b}]}$ \\
\hline 1 & $\mathrm{H}(\mathbf{1 d})$ & 25 & 30 & ATA-303 & 59 & $>99(R)$ \\
\hline 2 & $H(1 d)$ & 15 & 30 & ATA-303 & 78 & $>99(R)$ \\
\hline 3 & $H(1 d)$ & 15 & 45 & ATA-303 & 97 & $>99(R)$ \\
\hline 4 & $\mathrm{H}(\mathbf{1 d})$ & 25 & 30 & ATA-237 & 45 & $98(S)$ \\
\hline 5 & $H(\mathbf{1 d})$ & 15 & 30 & ATA-237 & 57 & $>99(S)$ \\
\hline 6 & $\mathrm{H}(\mathbf{1 d})$ & 15 & 45 & ATA-237 & 57 & $93(S)$ \\
\hline 7 & OMe (1e) & 15 & 45 & ATA-025 & 94 & $>99(R)$ \\
\hline 8 & OMe (1e) & 15 & 45 & ATA-033 & 95 & $>99(R)$ \\
\hline 9 & $\mathrm{OMe}(\mathbf{1 e})$ & 15 & 45 & ATA-234 & 91 & $>99(S)$ \\
\hline 10 & $\operatorname{Me}(\mathbf{1 f})$ & 15 & 45 & ATA-025 & 98 & $>99(R)$ \\
\hline 11 & $\operatorname{Me}(\mathbf{1 f})$ & 15 & 45 & ATA-033 & 98 & $>99(R)$ \\
\hline 12 & $\operatorname{Me}(\mathbf{1 f})$ & 15 & 45 & ATA-234 & 89 & $>99(S)$ \\
\hline 13 & $\mathrm{~F}(\mathbf{1 g})$ & 15 & 45 & ATA-024 & 99 & $>99(R)$ \\
\hline 14 & $\mathrm{~F}(\mathbf{1 g})$ & 15 & 45 & ATA-025 & 98 & $>99(R)$ \\
\hline 15 & $\mathrm{~F}(\mathbf{1 g})$ & 15 & 45 & ATA-415 & 99 & $>99(R)$ \\
\hline 16 & $\mathrm{~F}(\mathbf{1 g})$ & 15 & 45 & ATA-234 & 81 & $>99(S)$ \\
\hline 17 & Et (1h) & 15 & 45 & ATA-025 & 83 & $>99(R)$ \\
\hline 18 & Et (1h) & 15 & 45 & ATA-033 & 86 & $>99(R)$ \\
\hline 19 & Et (1h) & 15 & 45 & ATA-234 & 82 & $>99(S)$ \\
\hline
\end{tabular}

${ }^{[\mathrm{a}]}$ Conversion values determined by GC (see Supporting Information). ${ }^{[\mathrm{b}]}$ Determined by HPLC using chiral columns (see Supporting Information). Absolute configurations of the corresponding lactams $\mathbf{3 d - h}$ appear in brackets. 
Next, the enzymatic study over methyl 4-aryl-4oxobutanonates was envisaged, firstly starting from commercially available methyl 4-oxo-4phenylbutanoate (1d), and later extending the study to compounds bearing different substitution patterns at the para-position of the aromatic ring (OMe, Me, F and Et). These keto esters 1e-h were obtained through esterification of the corresponding carboxylic acids with refluxing methanol in acidic media (98-99\%). Subsequent reductive amination using sodium cyanoborohydride and ammonium acetate at room temperature led to the synthesis of the racemic lactams 3d-h (59-74\%), used as references for the enzymatic transformations.

$\gamma$-Keto ester 1d was initially studied and the best results are summarised in Table 2. In most of the cases, a lower reactivity was detected in comparison with alkylated esters 1a-c (see Tables S3-S5 in the Supporting Information for additional data). In fact, conversions lower than $60 \%$ were attained when working at $25 \mathrm{mM}$ substrate concentration (entries 1 and 4), even with the best candidates. In order to reach higher conversions maintaining the excellent selectivity towards the synthesis of $\mathbf{3 d}$, two reaction parameters were analysed: the substrate concentration $\left(15 \mathrm{mM}\right.$, entries 2 and 5) and the temperature $\left(45^{\circ} \mathrm{C}\right.$, entries 3 and 6). Remarkably, in the case of ATA-303 it was possible to obtain enantiopure $(R)-\mathbf{3 d}$ in $97 \%$ conversion at $15 \mathrm{mM}$ concentration and $45^{\circ} \mathrm{C}$.

Under these conditions, keto esters 1e-h (entries 719) were transformed, yielding in all cases the lactams in enantiomerically pure form and in $81-99 \%$ conversion, depending on the enzyme (see Tables S6S9 in the Supporting Information for extensive screenings). Interestingly, ATA-025 and ATA-033 were found as very robust enzymes for the formation of the $(R)$-enantiomers, while ATA-234 allowed the formation of their antipodes in a complete selective manner, and much higher conversions in comparison with the one achieved with the non-substituted keto ester 1d (56\% conversion and 97\% ee, see Table S5 in the Supporting Information).

As a continuation, 5-aryl-5-oxopentanoates $1 \mathbf{i}$ and 1j were selected in order to obtain the corresponding 6-arylpiperidin-2-ones $\mathbf{3 i}$ and $\mathbf{3 j}$. Firstly, the chemical syntheses of both keto esters and the corresponding lactams were carried out, following identical procedures than the ones described for $\mathbf{1 e - h}$ and $\mathbf{3 d}-\mathbf{h}$. In general, biotransamination experiments led to lower conversion values in comparison with the results obtained with the homologue butanoates 1d and $\mathbf{1 g}$ (Table 3 and see additional data in Tables S10 and S11 in the Supporting Information). An increase in the temperature led to a conversion improvement for the $(R)$-selective ATA-033 and ATA-025 (entries 1-2 and 7-8), although this failed for ATA-415, which led to the best conversion value towards enantiopure $(R)-3 \mathbf{i}$ at $30{ }^{\circ} \mathrm{C}$ (entries 3 and 4 ). ( $S$ )Selective ATA-237 displayed the highest activities (94-96\% conversion) acting with a high stereocontrol (93-95\% ee, entries 6 and 10$)$ at $45^{\circ} \mathrm{C}$.

Driving the equilibrium towards the formation of amine products is a key issue in transaminasecatalysed reactions, as the reductive amination process is thermodynamically hampered; therefore, a large molar excess of the amine donor is required. In the last years, the search for novel smart co-substrates or the in situ removal of the formed co-products have been applied. ${ }^{[15]}$ The advantage of the present strategy is the formation of an amine intermediate that cyclises in the same reaction medium forming the final lactam, so the reversibility of the equilibrium should be dramatically diminished. For that reason, we envisaged the use of lower contents of isopropylamine and the results have been summarised in Figure 2 (for numerical data see Table S12).

Table 3. Stereoselective transformation of $\delta$-keto esters $\mathbf{1} \mathbf{i}, \mathbf{j}$ into 6-arylpiperidin-2-ones $\mathbf{3 i}, \mathbf{j}$.
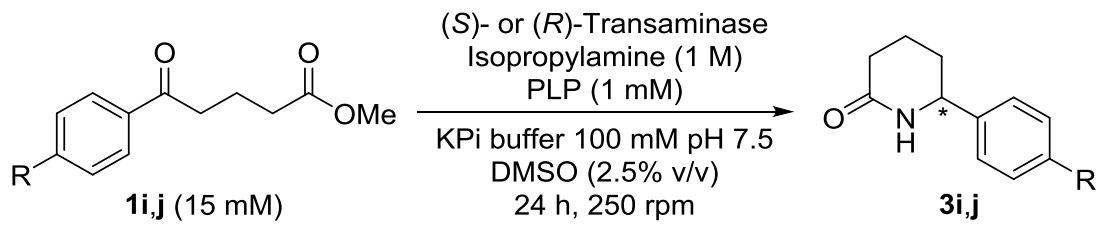

\begin{tabular}{|c|c|c|c|c|c|c|}
\hline Entry & Keto ester & $\mathrm{R}$ & $\mathrm{T}\left[{ }^{\circ} \mathrm{C}\right]$ & Transaminase & $c[\%]^{[\mathrm{a}]}$ & $e e[\%]^{[\mathrm{b}]}$ \\
\hline 1 & $\mathbf{1 i}$ & $\mathrm{H}$ & 30 & ATA-033 & 20 & $>99(R)$ \\
\hline 2 & $\mathbf{1 i}$ & $\mathrm{H}$ & 45 & ATA-033 & 28 & $>99(R)$ \\
\hline 3 & $\mathbf{1 i}$ & $\mathrm{H}$ & 30 & ATA-415 & 71 & $>99(R)$ \\
\hline 4 & $1 \mathbf{i}$ & $\mathrm{H}$ & 45 & ATA-415 & 47 & $>99(R)$ \\
\hline 5 & $1 \mathrm{i}$ & $\mathrm{H}$ & 30 & ATA-237 & 94 & $94(S)$ \\
\hline 6 & $1 \mathbf{i}$ & $\mathrm{H}$ & 45 & ATA-237 & 94 & $95(S)$ \\
\hline 7 & $\mathbf{1 j}$ & $F$ & 30 & ATA-025 & 43 & $>99(R)$ \\
\hline 8 & $\mathbf{1 j}$ & $\mathrm{F}$ & 45 & ATA-025 & 58 & $>99(R)$ \\
\hline 9 & $\mathbf{1 j}$ & $\mathrm{F}$ & 30 & ATA-237 & 90 & $92(S)$ \\
\hline 10 & $\mathbf{1 j}$ & $\mathrm{F}$ & 45 & ATA-237 & 96 & $93(S)$ \\
\hline
\end{tabular}

${ }^{[\mathrm{a}]}$ Conversion values determined by GC (see Supporting Information). ${ }^{[\mathrm{b}]}$ Determined by HPLC using chiral columns (see Supporting Information). Absolute configurations of the corresponding lactams $\mathbf{3 i}$ and $\mathbf{3} \mathbf{j}$ appear in brackets. 


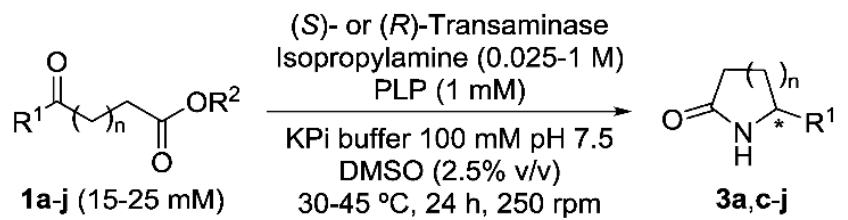

A)

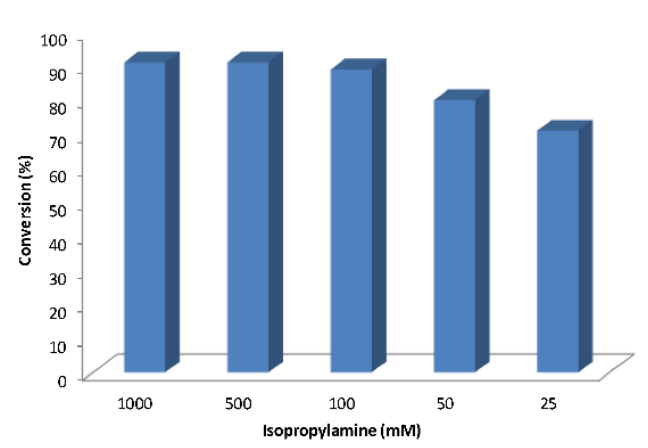

B)

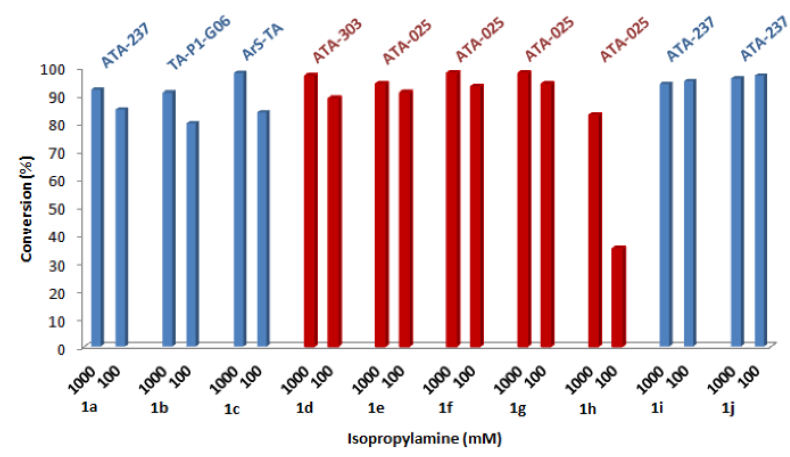

Figure 2. Influence of the isopropylamine concentration in the TA-catalysed transformation of keto esters 1a-j into lactams 3a,c-j. Blue colour denotes the production of $(S)$-amines $(89->99 \% e e)$, while red bars are used to indicate $(R)$ amines $(>99 \%$ ee). Figure 2A (left): Biotransamination of keto ester 1b into lactam 3a using TA-P1-G06 under the following conditions: $25 \mathrm{mM} \mathrm{1b}, 25-1000 \mathrm{mM}^{i} \mathrm{PrNH}_{2}, 30{ }^{\circ} \mathrm{C}, 24 \mathrm{~h}$ and $250 \mathrm{rpm}$. Figure $2 \mathrm{~B}$ (right): Biotransamination of keto esters 1a-j into lactams 3a,c-j under the following conditions: for 1a-c, $25 \mathrm{mM}$ keto ester, 0.1 or $1 \mathrm{M}^{i} \mathrm{PrNH}_{2}, 30{ }^{\circ} \mathrm{C}$, $24 \mathrm{~h}$ and $250 \mathrm{rpm}$; for $\mathbf{1 d - j}, 15 \mathrm{mM}$ keto ester, 0.1 or $1 \mathrm{M}^{i} \mathrm{PrNH}_{2}, 45^{\circ} \mathrm{C}, 24 \mathrm{~h}$ and $250 \mathrm{rpm}$.

Methyl levulinate $(\mathbf{1 b}, 25 \mathrm{mM})$ was selected as model substrate, and the biotransformations with TAP1-G06 at $30{ }^{\circ} \mathrm{C}$ were carried out using from an equimolar amount to a 40-molar excess of IPA (Figure 2A). After $24 \mathrm{~h}$, similar conversions (89$91 \%$ ) were found between 0.1-1 M IPA concentrations, observing a significant decrease at 50 $\mathrm{mM}$ IPA concentration (80\%). Even at equimolar amount, a high conversion was still observed (71\%). Then, the transaminase-catalysed reactions with all the previously tested substrates (Figure 2B) were carried out at 0.1 and $1 \mathrm{M}$ IPA concentrations, finding in general slightly lower conversions at lower IPA contents, although a clear negative effect was only remarkable for the case of $\mathbf{1 h}$.

Finally, preparative biotransformations (up to 100$\mathrm{mg}$ scale) were carried out under the optimised reaction conditions using $1 \mathrm{M}$ of IPA in order to assure very high conversions (Table 4), yielding in all cases the desired lactams with good to high isolated yields (66-89\%) and in general excellent selectivities (94->99\% ee). Cosolvents with a lower boiling point than DMSO were used, such as MeCN for commercially available TAs, and MTBE for ArS-TA, searching for high-yielding processes towards the final products with easier work-up protocols. Optical rotation values were measured for all the isolated lactam products, and their values compared with reported data in order to assign their absolute configurations. $^{[16-20]}$

Keto esters 1a-c bearing an alkyl substitution attached to the ketone functionality were used at 25
$\mathrm{mM}$ substrate concentration and $30{ }^{\circ} \mathrm{C}$, while for aromatic compounds $\mathbf{1 d}-\mathbf{j}$ the substrate concentration was reduced to $15 \mathrm{mM}$, and a higher temperature (45 ${ }^{\circ} \mathrm{C}$ ) was required to reach conversions over $70 \%$. As previously observed in Figure 2, the use of a lower amount of IPA $(100 \mathrm{mM})$ could also lead to practical processes (entries 6 and 12). Thus, $(S)$ - and $(R)$ selective TAs were chosen for preparative biotransformations and the amount of IPA was 10fold reduced, obtaining high conversions $(89-93 \%)$ and good to excellent selectivities $(91->99 \%$ ee) for substrates $\mathbf{1 e}$ and $\mathbf{1 j}$.

\section{Conclusions}

A simple and straightforward one-pot two-step process has been described for the transformation of different $\gamma$ - and $\delta$-keto esters into the corresponding optically active lactams. The strategy is based on a selective biotransamination reaction that allows the formation of the amino ester intermediates, which undergo spontaneous intramolecular cyclisation in the own aqueous medium without the addition of external reagents. Overall, this is a general process as it was extended to 10 substrates with different substitution patterns. Amino ester intermediates were not detected in any case, facilitating the isolation of the final optically active lactam products. 
Table 4. Stereoselective transformations of keto esters $\mathbf{1 b}-\mathbf{j}$ into lactams $\mathbf{3 a}, \mathbf{c}-\mathbf{j}$ under preparative scale.

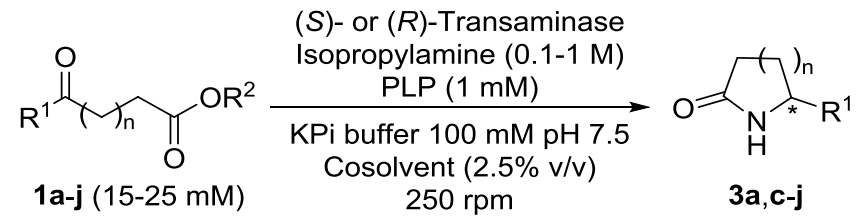

\begin{tabular}{lllllllll}
\hline Entry & {$[$ Keto ester $]$} & {$\left[{ }^{i} \mathrm{PrNH}_{2}\right][\mathrm{M}]$} & $\mathrm{T}\left[{ }^{\circ} \mathrm{C}\right]$ & Transaminase & Cosolvent & $\mathrm{t}[\mathrm{h}]$ & $c[\%]^{[\mathrm{a}]}$ & $e e[\%]^{\mathrm{b}]}$ \\
\hline 1 & $25(\mathbf{1 a})$ & 1 & 30 & ATA-237 & $\mathrm{MeCN}$ & 24 & $97(75)$ & $>99(S)$ \\
2 & $25(\mathbf{1 b})$ & 1 & 30 & TA-P1-G06 & $\mathrm{MeCN}$ & 48 & $88(80)$ & $>99(S)$ \\
3 & $25(\mathbf{1 c})$ & 1 & 30 & ArS-TA & MTBE & 24 & $98(89)$ & $>99(S)$ \\
4 & $15(\mathbf{1 d})$ & 1 & 45 & ATA-303 & $\mathrm{MeCN}$ & 24 & $97(88)$ & $>99(R)$ \\
5 & $15(\mathbf{1 e})$ & 1 & 45 & ATA-025 & $\mathrm{MeCN}$ & 48 & $82(74)$ & $>99(R)$ \\
6 & $15(\mathbf{1 e})$ & 0.1 & 45 & ATA-025 & $\mathrm{MeCN}$ & 48 & $89(80)$ & $>99(R)$ \\
7 & $15(\mathbf{1 f})$ & 1 & 45 & ATA-025 & $\mathrm{MeCN}$ & 48 & $91(86)$ & $>99(R)$ \\
8 & $15(\mathbf{1 g})$ & 1 & 45 & ATA-025 & $\mathrm{MeCN}$ & 48 & $80(75)$ & $>99(R)$ \\
9 & $15(\mathbf{1 h})$ & 1 & 45 & ATA-025 & $\mathrm{MeCN}$ & 48 & $89(81)$ & $>99(R)$ \\
10 & $15(\mathbf{1 i})$ & 1 & 45 & ATA-237 & $\mathrm{MeCN}$ & 24 & $77(70)$ & $94(S)$ \\
11 & $15(\mathbf{1 j})$ & 1 & 45 & ATA-237 & $\mathrm{MeCN}$ & 24 & $70(66)$ & $96(S)$ \\
12 & $15(\mathbf{1 j})$ & 0.1 & 45 & ATA-237 & $\mathrm{MeCN}$ & 24 & $93(90)$ & $91(S)$ \\
\hline
\end{tabular}

${ }^{[a]}$ Conversion values determined by GC (see Supporting Information). Isolated yields appear in brackets. ${ }^{[b]}$ Determined by HPLC using chiral columns (see Supporting Information). Absolute configurations of the corresponding lactams 3a,c-j appear in brackets.

Chiral 6-substituted piperidin-2-ones and 5substituted pyrrolidin-2-ones were obtained with high optical purity (94->99\% ee) and generally in good to very high yields $(66-90 \%)$ for selected preparative biotransformations, the choice of the transaminase allowing the preparation of the desired lactam enantiomer under mild reaction conditions. Substrate concentration and temperature resulted to be key issues for driving the reactions to high conversions, being possible the reduction of the amine donor equivalents in selected cases without a significant drop of the conversion values due to the thermodynamically favoured intramolecular cyclisation process.

\section{Experimental Section}

\section{General methods}

Codex Transaminase ATA Screening Kit (ATASK000250) and pyridoxal 5'-phosphate (PLP) were purchased from Codexis. Transaminases from Chromobacterium violaceum (Cv-TA, internal plasmid number pET20) and Arthrobacter sp. [ArR-TA (pEG23), ArS-TA (pEG29) and ArRmut11-TA (pEG90)] overexpressed on E. coli cells were provided by Prof. Wolfgang Kroutil (University of Graz). ${ }^{[13 c]}$ All other reagents were obtained from commercial sources (Sigma-Aldrich, Acros, and Fluka) and used as received except dry methanol that was previously distilled under nitrogen using calcium hydride as desiccant.

NMR spectra were recorded on a Bruker AV300 MHz spectrometer. All chemical shifts $(\delta)$ are given in parts per million (ppm) and referenced to the residual solvent signal as internal standard. IR spectra were recorded on a Bruker ALPHA spectrophotometer on $\mathrm{NaCl}$ pellets or $\mathrm{KBr}$ pellets. $v_{\max }$ values are given for the main absorption bands. High resolution mass spectra (HRMS) were obtained in a Micro Tof Q spectrometer using $\mathrm{ESI}^{+}$or $\mathrm{ESI}^{-}$. Measurement of the optical rotation values was carried out at $590 \mathrm{~nm}$ on a PerkinElmer 241 polarimeter.

Gas chromatography (GC) and high performance liquid chromatography (HPLC) analyses were performed for conversion and enantiomeric excess measurements (see the Supporting Information). GC analyses were performed on an Agilent HP7820 GC chromatograph equipped with a FID detector. HPLC analyses were carried out in a Hewlett Packard 1100 chromatograph UV detector at $210 \mathrm{~nm}$. Thin-layer chromatography (TLC) was conducted with Merck Silica Gel 60 F254 precoated plates and visualised with UV and potassium permanganate stain. Column chromatography was performed using Merck Silica Gel 60 (230-400 mesh).

General procedure for the chemical synthesis of $\gamma$-keto esters $1 \mathrm{e}-\mathrm{h}$ and $\boldsymbol{\delta}$-keto esters $1 \mathbf{i}$ and $1 \mathbf{j}$. To a solution of the corresponding keto acid $\mathbf{4 e - j}(1.6 \mathrm{mmol})$ in $\mathrm{MeOH}(8$ $\mathrm{mL}, 0.2 \mathrm{M}$ ), a few drops of concentrated sulfuric acid were added at room temperature. The mixture was stirred and heated at $68{ }^{\circ} \mathrm{C}$ overnight. After this time, $\mathrm{H}_{2} \mathrm{O}(10 \mathrm{~mL})$ was added. The mixture was neutralised with an aqueous $\mathrm{NaOH} 2 \mathrm{M}$ solution and the product was extracted with $\mathrm{CH}_{2} \mathrm{Cl}_{2}(3 \times 15 \mathrm{~mL})$. The organic layers were combined dried over $\mathrm{Na}_{2} \mathrm{SO}_{4}$ and concentrated under reduced pressure, isolating the corresponding keto esters $\mathbf{1 e - h}, \mathbf{i}, \mathbf{j}$ in excellent purity, which were later used without further purification $(91-99 \%)$.

Methyl 4-(4-methoxyphenyl)-4-oxobutanoate (1e). Yellowish solid (323 $\mathrm{mg}, 99 \%$ yield). $R_{\mathrm{f}}(50 \%$ EtOAc/Hexane): 0.4. Mp: 46-47 ${ }^{\circ} \mathrm{C}$. IR (KBr): $v$ 3058, 2954, 2918, 2844, 1737, 1602, 1439, 1318, 1030, $737 \mathrm{~cm}^{-1}$. ${ }^{1} \mathrm{H}$ NMR $\left(300.13 \mathrm{MHz}, \mathrm{CDCl}_{3}\right): \delta 2.73\left(\mathrm{t},{ }^{3} J_{\mathrm{HH}}=6.7 \mathrm{~Hz}\right.$, $2 \mathrm{H}), 3.25\left(\mathrm{t},{ }^{3} J_{\mathrm{HH}}=6.7 \mathrm{~Hz}, 2 \mathrm{H}\right), 3.68(\mathrm{~s}, 3 \mathrm{H}), 3.84(\mathrm{~s}, 3 \mathrm{H})$ $6.92\left(\mathrm{~d},{ }^{3} J_{\mathrm{HH}}=8.9 \mathrm{~Hz}, 2 \mathrm{H}\right), 7.94\left(\mathrm{~d},{ }^{3} J_{\mathrm{HH}}=8.9 \mathrm{~Hz}, 2 \mathrm{H}\right)$ ${ }^{13} \mathrm{C}$ NMR $\left(300.13 \mathrm{MHz}, \mathrm{CDCl}_{3}\right): \delta 28.0\left(\mathrm{CH}_{2}\right), 32.9\left(\mathrm{CH}_{2}\right)$, $51.7\left(\mathrm{CH}_{3}\right), 55.4\left(\mathrm{CH}_{3}\right), 113.7(2 \mathrm{CH}), 129.5(\mathrm{C}), 130.2(2$ $\mathrm{CH}), 163.5(\mathrm{C}), 173.4(\mathrm{C}), 196.5(\mathrm{C}) . \mathrm{HRMS}\left(\mathrm{ESI}^{+}, \mathrm{m} / \mathrm{z}\right)$ calcd for $\left(\mathrm{C}_{12} \mathrm{H}_{14} \mathrm{NaO}_{4}\right)^{+} \quad(\mathrm{M}+\mathrm{Na})^{+}$245.0784; found 245.0780 .

Methyl 4-(4-methylphenyl)-4-oxobutanoate (1f) Yellowish solid (322 mg, 99\% yield). $R_{\mathrm{f}} \quad(50 \%$ EtOAc/Hexane): 0.63. Mp: 51-52 ${ }^{\circ} \mathrm{C}$. IR (KBr): $v 3057$ 2990, 2953, 2921, 2850, 1737, 1608, 1438, 1307, 1029, $738 \mathrm{~cm}^{-1}$ H NMR (300.13 MHz, CDCl $\left.{ }_{3}\right): \delta 2.43(\mathrm{~s}, 3 \mathrm{H})$, $2.78\left(\mathrm{t},{ }^{3} J_{\mathrm{HH}}=6.7 \mathrm{~Hz}, 2 \mathrm{H}\right), 3.32\left(\mathrm{t},{ }^{3} J_{\mathrm{HH}}=6.7 \mathrm{~Hz}, 2 \mathrm{H}\right)$, 
$3.72(\mathrm{~s}, 3 \mathrm{H}), 7.28\left(\mathrm{~d},{ }^{3} J_{\mathrm{HH}}=7.8 \mathrm{~Hz}, 2 \mathrm{H}\right), 7.90\left(\mathrm{~d},{ }^{3} J_{\mathrm{HH}}=\right.$ $8.2 \mathrm{~Hz}, 2 \mathrm{H}) .{ }^{13} \mathrm{C} \mathrm{NMR}\left(300.13 \mathrm{MHz}, \mathrm{CDCl}_{3}\right): \delta 21.6$ $\left(\mathrm{CH}_{3}\right), 28.0\left(\mathrm{CH}_{2}\right), 33.2\left(\mathrm{CH}_{2}\right), 51.8\left(\mathrm{CH}_{3}\right), 128.1(2 \mathrm{CH})$, 129.2 (2 CH), 134.0 (C), 144.0 (C), 173.4 (C), 197.6 (C). HRMS $\left(\mathrm{ESI}^{+}, \mathrm{m} / z\right)$ : calcd for $\left(\mathrm{C}_{12} \mathrm{H}_{14} \mathrm{NaO}_{3}\right)^{+}(\mathrm{M}+\mathrm{Na})^{+}$ 229.0835; found 229.0831.

Methyl 4-(4-fluorophenyl)-4-oxobutanoate (1g). White solid $(210 \mathrm{mg}, 98 \%$ yield $) . R_{\mathrm{f}} \quad(50 \%$ EtOAc/Hexane): 0.37. Mp: 51-52 ${ }^{\circ} \mathrm{C}$. IR (KBr): v 3064 , 2954, 2918, 2850, 1738, 1599, 1439, 1412, 1268, 1157, $737 \mathrm{~cm}^{-1} .{ }^{1} \mathrm{H}$ NMR $\left(300.13 \mathrm{MHz}, \mathrm{CDCl}_{3}\right): \delta 2.76\left(\mathrm{t},{ }^{3} J_{\mathrm{HH}}=\right.$ $6.6 \mathrm{~Hz}, 2 \mathrm{H}), 3.29\left(\mathrm{t},{ }^{3} J_{\mathrm{HH}}=6.6 \mathrm{~Hz}, 2 \mathrm{H}\right), 3.70(\mathrm{~s}, 3 \mathrm{H}), 7.13$ $\left(\mathrm{t},{ }^{3} J_{\mathrm{HH}}=8.6 \mathrm{~Hz}, 2 \mathrm{H}\right), 8.01\left(\mathrm{dd},{ }^{3} J_{\mathrm{HH}}=8.9 \mathrm{~Hz},{ }^{3} J_{\mathrm{HF}}=5.4\right.$ $\mathrm{Hz}, 2 \mathrm{H}) .{ }^{13} \mathrm{C}$ NMR $\left(300.13 \mathrm{MHz}, \mathrm{CDCl}_{3}\right): \delta 27.9\left(\mathrm{CH}_{2}\right)$, $33.2\left(\mathrm{CH}_{2}\right), 51.8\left(\mathrm{CH}_{3}\right), 115.6\left(\mathrm{~d},{ }^{2} J_{\mathrm{CF}}=21.9 \mathrm{~Hz}, 2 \mathrm{CH}\right)$, $130.6\left(\mathrm{~d}_{\mathrm{p}}{ }^{3} J_{\mathrm{CF}}=9.3 \mathrm{~Hz}, 2 \mathrm{CH}\right), 132.9\left(\mathrm{~d},{ }^{4} J_{\mathrm{CF}}=2.8 \mathrm{~Hz}, \mathrm{C}\right)$, $165\left(\mathrm{~d},{ }^{\mathrm{P}} J_{\mathrm{CF}}=254.8 \mathrm{~Hz}, \mathrm{C}\right), 173.2(\mathrm{C}), 196.4$ (C). HRMS $\left(\mathrm{ESI}^{+}, \mathrm{m} / z\right)$ : calcd for $\left(\mathrm{C}_{11} \mathrm{H}_{11} \mathrm{FNaO}_{3}\right)^{+}(\mathrm{M}+\mathrm{Na})^{+} 233.0584$; found 233.0583

Methyl 4-(4-ethylphenyl)-4-oxobutanoate (1h). Yellowish oil $(528 \mathrm{mg}, 98 \%$ yield $) . \quad R_{\mathrm{f}} \quad(50 \%$ EtOAc/Hexane): 0.5. IR (NaCl): v 3057, 2969, 2920, 2877, $2850,1737,1607,1439,1415,1266,1169,738 \mathrm{~cm}^{-1} \cdot{ }^{1} \mathrm{H}$ $\operatorname{NMR}\left(300.13 \mathrm{MHz}, \mathrm{CDCl}_{3}\right): \delta 1.26\left(\mathrm{t},{ }^{3} J_{\mathrm{HH}}=7.6 \mathrm{~Hz}, 3 \mathrm{H}\right)$, 2.67-2.78 (m, 4H), 3.30 (t, $\left.{ }^{3} J_{\mathrm{HH}}=6.7 \mathrm{~Hz}, 2 \mathrm{H}\right), 3.70(\mathrm{~s}, 3 \mathrm{H})$, $7.28\left(\mathrm{~d},{ }^{3} J_{\mathrm{HH}}=8.3 \mathrm{~Hz}, 2 \mathrm{H}\right), 7.91\left(\mathrm{~d},{ }^{3} J_{\mathrm{HH}}=8.3 \mathrm{~Hz}, 2 \mathrm{H}\right)$. ${ }^{3} \mathrm{C} \mathrm{NMR}\left(300.13 \mathrm{MHz}, \mathrm{CDCl}_{3}\right): \delta 15.1\left(\mathrm{CH}_{3}\right), 28.0\left(\mathrm{CH}_{2}\right)$, $28.9\left(\mathrm{CH}_{2}\right), 33.2\left(\mathrm{CH}_{2}\right), 51.7\left(\mathrm{CH}_{3}\right), 128.0(2 \mathrm{CH}), 128.2(2$ $\mathrm{CH}), 134.2$ (C), 150.1 (C), 173.4 (C), 197.6 (C). HRMS $\left(\mathrm{ESI}^{+}, \mathrm{m} / \mathrm{z}\right)$ : calcd for $\left(\mathrm{C}_{13} \mathrm{H}_{16} \mathrm{NaO}_{3}\right)^{+}(\mathrm{M}+\mathrm{Na})^{+} 243.0992$; found 243.0990 .

Methyl 5-oxo-phenylpentanoate (1i). Yellowish oil (489 mg, 92\% yield). $R_{\mathrm{f}}(50 \%$ EtOAc/Hexane): 0.57 . IR (KBr): v 3057, 2986, 2953, 2848, 1735, 1449, 1419, 1372, $1266,1179,704,692 \mathrm{~cm}^{-1}$. ${ }^{1} \mathrm{H}$ NMR $(300.13 \mathrm{MHz}$, $\left.\mathrm{CDCl}_{3}\right): \delta 2.08$ quin $\left._{3}^{3} J_{\mathrm{HH}}=7.1 \mathrm{~Hz}, 2 \mathrm{H}\right), 2.44\left(\mathrm{t},{ }^{3} J_{\mathrm{HH}}=\right.$ $7.2 \mathrm{~Hz}, 2 \mathrm{H}), 3.04\left(\mathrm{t},{ }^{3} J_{\mathrm{HH}}=7.1 \mathrm{~Hz}, 2 \mathrm{H}\right), 3.66(\mathrm{~s}, 3 \mathrm{H}), 7.44$ $(\mathrm{m}, 2 \mathrm{H}), 7.54(\mathrm{~m}, 1 \mathrm{H}), 7.95\left(\mathrm{dd},{ }^{3} J_{\mathrm{HH}}=8.4 \mathrm{~Hz},{ }^{4} J_{\mathrm{HH}}=1.4\right.$ $\mathrm{Hz}, 2 \mathrm{H}) \cdot{ }^{13} \mathrm{C}$ NMR $\left(300.13 \mathrm{MHz}, \mathrm{CDCl}_{3}\right): \delta 19.3\left(\mathrm{CH}_{2}\right)$, $33.0\left(\mathrm{CH}_{2}\right), 37.4\left(\mathrm{CH}_{2}\right), 51.5\left(\mathrm{CH}_{3}\right), 127.9(2 \mathrm{CH}), 128.5(2$ $\mathrm{CH}), 133.0$ (CH), 136.7 (C), 173.6 (C), 199.3 (C). HRMS $\left(\mathrm{ESI}^{+}, \mathrm{m} / \mathrm{z}\right)$ : calcd for $\left(\mathrm{C}_{12} \mathrm{H}_{14} \mathrm{NaO}_{3}\right)^{+}(\mathrm{M}+\mathrm{Na})^{+} 229.0835$; found 229.0835

Methyl 5-(4-fluorophenyl)-5-oxopentanoate (1j). White solid (504 mg, 91\% yield). $R_{\mathrm{f}} \quad(50 \%$ EtOAc/Hexane): 0.33 . Mp: $46-47{ }^{\circ} \mathrm{C}$. IR (KBr): v 3059, 2953, 2849, 1735, 1598, 1410, 1371, 1267, 1157, $738 \mathrm{~cm}^{-1}$ ${ }^{1} \mathrm{H}$ NMR $\left(300.13 \mathrm{MHz}, \mathrm{CDCl}_{3}\right.$ ): $\delta 2.06$ (quin, ${ }^{3} J_{\mathrm{HH}}=7.1$ $\mathrm{Hz}, 2 \mathrm{H}), 2.46\left(\mathrm{t},{ }^{3} J_{\mathrm{HH}}=7.1 \mathrm{~Hz}, 2 \mathrm{H}\right), 3.04\left(\mathrm{t},{ }^{3} J_{\mathrm{HH}}=7.1 \mathrm{~Hz}\right.$, $2 \mathrm{H}), 3.60(\mathrm{~s}, 3 \mathrm{H}), 7.14\left(\mathrm{t},{ }^{3} J_{\mathrm{HH}}=8.6 \mathrm{~Hz}, 2 \mathrm{H}\right), 8.00(\mathrm{dd}$, $\left.{ }^{3} J_{\mathrm{HH}}=8.9 \mathrm{~Hz},{ }^{3} J_{\mathrm{HF}}=5.4 \mathrm{~Hz}, 2 \mathrm{H}\right) .{ }^{13} \mathrm{C} \mathrm{NMR}(300.13 \mathrm{MHz}$, $\left.\mathrm{CDCl}_{3}\right): \delta_{2} 19.3\left(\mathrm{CH}_{2}\right), 33.0\left(\mathrm{CH}_{2}\right), 37.3\left(\mathrm{CH}_{2}\right), 51.6\left(\mathrm{CH}_{3}\right)$, $115.6\left(\mathrm{~d},{ }^{2} J_{\mathrm{CF}}=21.8 \mathrm{~Hz}, 2 \mathrm{CH}\right), 130.6\left(\mathrm{~d},{ }^{3} J_{\mathrm{CF}}=9.4 \mathrm{~Hz}, 2\right.$ $\mathrm{CH}), 133.2\left(\mathrm{~d},{ }^{4} J_{\mathrm{CF}}=3.3 \mathrm{~Hz}, \mathrm{C}\right), 165.0\left(\mathrm{~d},{ }^{1} J_{\mathrm{CF}}=254.9 \mathrm{~Hz}\right.$, C), 173.6 (C), 197.7 (C). HRMS (ESI $\left.{ }^{+} \mathrm{m} / \mathrm{z}\right)$ : calcd for $\left(\mathrm{C}_{12} \mathrm{H}_{13} \mathrm{FNaO}_{3}\right)^{+}(\mathrm{M}+\mathrm{Na})^{+} 247.0741$; found 247.0742 .

General procedure for the chemical synthesis of racemic $\gamma$-lactams $3 d-h$ and $\delta$-lactams $3 i$ and $3 j$. In order to develop robust analytical methods for monitoring the biotransaminations, the synthesis of racemic lactams was previously chemically performed in the following manner: Ammonium acetate $(200 \mathrm{mg}, 2.6 \mathrm{mmol})$ and sodium cyanoborohydride (33 $\mathrm{mg}, 0.52 \mathrm{mmol})$ were successively added to a solution of the corresponding keto ester 1d-j $(0.26 \mathrm{mmol})$ in dry $\mathrm{MeOH}(1.0 \mathrm{~mL})$ under inert atmosphere. The mixture was stirred at room temperature during $16 \mathrm{~h}$ and, after this time, $\mathrm{H}_{2} \mathrm{O}(5 \mathrm{~mL})$ was added to quench the reaction. The solution was basified until $\mathrm{pH}$ around 11 by adding a saturated aqueous solution of $\mathrm{Na}_{2} \mathrm{CO}_{3}$. Then the mixture was extracted with $\mathrm{Et}_{2} \mathrm{O}(3 \times 10$ $\mathrm{mL}$ ) and the organic layers were combined, dried over $\mathrm{Na}_{2} \mathrm{SO}_{4}$ and concentrated under reduced pressure. The product was purified by chromatography column on silica gel $\left(2 \% \mathrm{MeOH} / \mathrm{CH}_{2} \mathrm{Cl}_{2}\right)$, affording the racemic lactams 3dj $(48-74 \%)$.

5-Phenylpyrrolidin-2-one (3d). White solid (29 mg, $74 \%$ yield). $R_{\mathrm{f}}\left(5 \% \mathrm{MeOH} / \mathrm{CH}_{2} \mathrm{Cl}_{2}\right): 0.38 . \mathrm{Mp}: 107-108^{\circ} \mathrm{C}$ IR (KBr): v 3055, 2959, 2926, 2872, 2858, 1687, 1266, 1157, 740, $705 \mathrm{~cm}^{-1} .{ }^{1} \mathrm{H}$ NMR $\left(300.13 \mathrm{MHz}, \mathrm{CDCl}_{3}\right): \delta$
1.94-2.06 (m, 1H), 2.38-2.52 (m, 2H), 2.54-2.66 (m, 1H), $4.78\left(\mathrm{t}, 3 J_{\mathrm{HH}}=7.1 \mathrm{~Hz}, 1 \mathrm{H}\right), 6.01(\mathrm{br} \mathrm{s}, 1 \mathrm{H}), 7.28-7.42(\mathrm{~m}$ $5 \mathrm{H}) .{ }^{13} \mathrm{C}$ NMR $\left(300.13 \mathrm{MHz}, \mathrm{CDCl}_{3}\right): \delta 30.2\left(\mathrm{CH}_{2}\right), 31.4$ $\left(\mathrm{CH}_{2}\right), 58.0(\mathrm{CH}), 125.6(2 \mathrm{CH}), 127.9(\mathrm{CH}), 128.9(2 \mathrm{CH})$, 142.3 (C), 178.4 (C). HRMS $\left(\mathrm{ESI}^{+}, \mathrm{m} / \mathrm{z}\right)$ : calcd for $\left(\mathrm{C}_{10} \mathrm{H}_{11} \mathrm{NNaO}\right)^{+}(\mathrm{M}+\mathrm{Na})^{+}$184.0733; found 184.0735.

5-(4-Methoxyphenyl)pyrrolidin-2-one (3e). Yellowish solid (26 mg, $60 \%$ yield). $R_{\mathrm{f}}\left(5 \% \mathrm{MeOH} / \mathrm{CH}_{2} \mathrm{Cl}_{2}\right): 0.43$ Mp: $115-116{ }^{\circ} \mathrm{C}$. IR (KBr): v 3426, 3055, 2986, 1696 , 1265, 1035, $739 \mathrm{~cm}^{-1}$. $\mathrm{H}$ NMR $\left(300.13 \mathrm{MHz}, \mathrm{CDCl}_{3}\right): \delta$ $1.96(\mathrm{~m}, 1 \mathrm{H}), 2.39-2.56(\mathrm{~m}, 3 \mathrm{H}), 3.80(\mathrm{~s}, 3 \mathrm{H}), 4.71\left(\mathrm{t},{ }^{3} J_{\mathrm{HH}}\right.$ $=7.0 \mathrm{~Hz}, 1 \mathrm{H}), 6.44(\mathrm{br} \mathrm{s}, 1 \mathrm{H}), 6.89\left(\mathrm{~d},{ }^{3} J_{\mathrm{HH}}=8.7 \mathrm{~Hz}, 2 \mathrm{H}\right)$, $7.21\left(\mathrm{~d},{ }^{3} J_{\mathrm{HH}}=8.7 \mathrm{~Hz}, 2 \mathrm{H}\right) .{ }^{13} \mathrm{C}$ NMR $(300.13 \mathrm{MHz}$, $\left.\mathrm{CDCl}_{3}\right): \delta 30.4\left(\mathrm{CH}_{2}\right), 31.5\left(\mathrm{CH}_{2}\right), 55.3\left(\mathrm{CH}_{3}\right), 57.6(\mathrm{CH})$ $114.2(2 \mathrm{CH}), 126.8(2 \mathrm{CH}), 134.4(\mathrm{C}), 159.2(\mathrm{C}), 178.4$ (C). HRMS $\left(\mathrm{ESI}^{+}, \mathrm{m} / \mathrm{z}\right)$ : calcd for $\left(\mathrm{C}_{11} \mathrm{H}_{13} \mathrm{NNaO}_{2}\right)^{+}$ $(\mathrm{M}+\mathrm{Na})^{+} 214.0838$; found 214.0836 .

5-(4-Methylphenyl)pyrrolidin-2-one (3f). White solid (31 mg, $73 \%$ yield). $R_{\mathrm{f}}\left(5 \% \mathrm{MeOH} / \mathrm{CH}_{2} \mathrm{Cl}_{2}\right): 0.5$. Mp: 89$90^{\circ} \mathrm{C}$. IR (KBr): $v$ 3425, 3054, 2985, 2922, 2852, 1695 $1266,1156,738,705 \mathrm{~cm}^{-1} .{ }^{1} \mathrm{H}$ NMR $(300.13 \mathrm{MHz}$, $\left.\mathrm{CDCl}_{3}\right): \delta 1.93-2.06(\mathrm{~m}, 1 \mathrm{H}), 2.38(\mathrm{~s}, 3 \mathrm{H}), 2.45(\mathrm{~m}, 2 \mathrm{H})$ $2.51-2.62(\mathrm{~m}, 1 \mathrm{H}), 4.73\left(\mathrm{t},{ }^{3} J_{\mathrm{HH}}=7.1 \mathrm{~Hz}, 1 \mathrm{H}\right), 6.23(\mathrm{br} \mathrm{s}$ $1 \mathrm{H}), 7.14-7.28(\mathrm{~m}, 4 \mathrm{H}) \cdot{ }^{13} \mathrm{C} \mathrm{NMR}\left(300.13 \mathrm{MHz}^{-} \mathrm{CDCl}_{3}\right): \delta$ $21.0\left(\mathrm{CH}_{3}\right), 30.3\left(\mathrm{CH}_{2}\right), 31.4\left(\mathrm{CH}_{2}\right), 57.8(\mathrm{CH}), 126.2(2$ $\mathrm{CH}), 129.2(2 \mathrm{CH}), 137.7$ (C), 139.4 (C), $178.4(\mathrm{C})$. HRMS $\left(\mathrm{ESI}^{+}, \mathrm{m} / \mathrm{z}\right)$ : calcd for $\left(\mathrm{C}_{11} \mathrm{H}_{13} \mathrm{NNaO}\right)^{+}(\mathrm{M}+\mathrm{Na})^{+}$ 198.0889; found 198.0888 .

5-(4-Fluorophenyl)pyrrolidin-2-one (3g). White solid (25 mg, $59 \%$ yield). $R_{\mathrm{f}}\left(5 \% \mathrm{MeOH} / \mathrm{CH}_{2} \mathrm{Cl}_{2}\right): 0.5$. Mp: 138 $139^{\circ} \mathrm{C}$. IR (KBr): v 3425, 3055, 2986, 2924, 1698, 1606 , $1512,1422,1265,738 \mathrm{~cm}^{-1} .{ }^{1} \mathrm{H}$ NMR $(300.13 \mathrm{MHz}$, $\left.\mathrm{CDCl}_{3}\right): \delta 1.88-2.00(\mathrm{~m}, 1 \mathrm{H}), 2.41-2.52(\mathrm{~m}, 2 \mathrm{H}), 2.58(\mathrm{~m}$ $1 \mathrm{H}), 4.78\left(\mathrm{t},{ }^{3} J_{\mathrm{HH}}=7.1 \mathrm{~Hz}, 1 \mathrm{H}\right), 7.05\left(\mathrm{t}^{3}{ }^{3} J_{\mathrm{HH}}=8.6 \mathrm{~Hz}, 2 \mathrm{H}\right)$, $7.08(\mathrm{~s}, 1 \mathrm{H}), 7.29\left(\mathrm{dd},{ }^{3} J_{\mathrm{HH}}=8.7 \mathrm{~Hz},{ }^{4} J_{\mathrm{HF}}=5.2 \mathrm{~Hz}, 2 \mathrm{H}\right)$ ${ }^{13} \mathrm{C}$ NMR $\left(300.13 \mathrm{MHz}, \mathrm{CDCl}_{3}\right): \delta 30.3\left(\mathrm{CH}_{2}\right), 31.4\left(\mathrm{CH}_{2}\right)$ $57.4(\mathrm{CH}), 115.7\left(\mathrm{~d},{ }^{2} J_{\mathrm{CF}}=21.6 \mathrm{~Hz}, 2 \mathrm{CH}\right), 127.3\left(\mathrm{~d},{ }^{3} J_{\mathrm{CF}}\right.$ $=8.1 \mathrm{~Hz}, 2 \mathrm{CH}), 130.7\left(\mathrm{~d},{ }^{4} J_{\mathrm{CF}}=3.1 \mathrm{~Hz}, \mathrm{C}\right), 162.0\left(\mathrm{~d},{ }^{1} J_{\mathrm{CF}}\right.$ $=246.1 \mathrm{~Hz}, \mathrm{C}), 178.3(\mathrm{C})$. HRMS $\left(\mathrm{ESI}^{+}, \mathrm{m} / \mathrm{z}\right)$ : calcd for $\left(\mathrm{C}_{10} \mathrm{H}_{10} \mathrm{FNNaO}\right)^{+}(\mathrm{M}+\mathrm{Na})^{+}$202.0639; found 202.0635.

5-(4-Ethylphenyl)pyrrolidin-2-one (3h). Yellowish solid (30 mg, $69 \%$ yield). $R_{\mathrm{f}}\left(5 \% \mathrm{MeOH} / \mathrm{CH}_{2} \mathrm{Cl}_{2}\right): 0.55$ Mp: $82-83{ }^{\circ} \mathrm{C}$. IR (KBr): v 3425, 3054, 2984, 2970, 2931, 1696, 1422, $1265,739 \mathrm{~cm}^{-1}$. ${ }^{1} \mathrm{H}$ NMR (300.13 MHz, $\left.\mathrm{CDCl}_{3}\right): \delta 1.24\left(\mathrm{t},{ }^{3} J_{\mathrm{HH}}=7.6 \mathrm{~Hz}, 3 \mathrm{H}\right), 1.99(\mathrm{~m}, 1 \mathrm{H}), 2.37-$ $2.47(\mathrm{~m}, 2 \mathrm{H}), 2.48-2.60(\mathrm{~m}, 1 \mathrm{H}), 2.66\left(\mathrm{q},{ }^{3} J_{\mathrm{HH}}=7.6 \mathrm{~Hz}\right.$ $2 \mathrm{H}), 4.74\left(\mathrm{t},{ }_{\mathrm{HH}}=7.1 \mathrm{~Hz}, 1 \mathrm{H}\right), 6.05($ br s, $1 \mathrm{H}), 7.24(\mathrm{~m}$, $4 \mathrm{H}) \cdot{ }^{13} \mathrm{C}$ NMR $\left(300.13 \mathrm{MHz}, \mathrm{CDCl}_{3}\right): \delta 15.5\left(\mathrm{CH}_{3}\right), 28.4$ $\left(\mathrm{CH}_{2}\right), 30.3\left(\mathrm{CH}_{2}\right), 31.4\left(\mathrm{CH}_{2}\right), 57.9(\mathrm{CH}), 125.6(2 \mathrm{CH})$ $128.3(2 \mathrm{CH}), 139.6(\mathrm{C}), 144.1$ (C), 178.3 (C). HRMS $\left(\mathrm{ESI}^{+}, \mathrm{m} / z\right)$ : calcd for $\left(\mathrm{C}_{12} \mathrm{H}_{15} \mathrm{NNaO}\right)^{+}(\mathrm{M}+\mathrm{Na})^{+} 212.1046$; found 212.1044.

6-Phenylpiperidin-2-one (3i). White solid (12 mg, 48\% yield). $R_{\mathrm{f}}\left(5 \% \mathrm{MeOH} / \mathrm{CH}_{2} \mathrm{Cl}_{2}\right): 0.46$. Mp: $112-113{ }^{\circ} \mathrm{C}$. IR $(\mathrm{KBr}): v 3389,3054,2985,2957,293,2853,1657,1265$ $738,704 \mathrm{~cm}^{-1} .{ }^{1} \mathrm{H}$ NMR $\left(300.13 \mathrm{MHz}, \mathrm{CDCl}_{3}\right): \delta 1.63-1.74$ $(\mathrm{m}, 1 \mathrm{H}), 1.76-1.86(\mathrm{~m}, 1 \mathrm{H}), 1.87-1.99(\mathrm{~m}, 1 \mathrm{H}), 2.03-2.17$ $(\mathrm{m}, 1 \mathrm{H}), 2.37-2.52(\mathrm{~m}, 2 \mathrm{H}), 4.57\left(\mathrm{dd},{ }^{3} \mathrm{~J}_{\mathrm{HH}}=8.8,4.6 \mathrm{~Hz}\right.$ $1 \mathrm{H}), 6.02(\mathrm{~s}, 1 \mathrm{H}), 7.28-7.43(\mathrm{~m}, 5 \mathrm{H}) .{ }^{3} \mathrm{C}$ NMR $(300.13$ $\left.\mathrm{MHz}, \mathrm{CDCl}_{3}\right): \delta 19.7\left(\mathrm{CH}_{2}\right), 31.3\left(\mathrm{CH}_{2}\right), 32.2\left(\mathrm{CH}_{2}\right), 57.8$ $(\mathrm{CH}), 126.0(2 \mathrm{CH}), 127.9(\mathrm{CH}), 128.8(2 \mathrm{CH}), 142.4(\mathrm{C})$ 172.3 (C). HRMS (ESI, $\mathrm{m} / \mathrm{z})$ : calcd for $\left(\mathrm{C}_{11} \mathrm{H}_{13} \mathrm{NNaO}\right)^{+}$ $(\mathrm{M}+\mathrm{Na})^{+}$198.0889; found 198.0887.

6-(4-Fluorophenyl)piperidin-2-one (3j). White solid (11 mg, $50 \%$ yield). $R_{\mathrm{f}}\left(5 \% \mathrm{MeOH} / \mathrm{CH}_{2} \mathrm{Cl}_{2}\right): 0.54$. Mp: 99 $100^{\circ} \mathrm{C}$. IR $(\mathrm{KBr}): v 3389,3055,2986,2930,1659,1265$ $739 \mathrm{~cm}^{-1}$. $\mathrm{H}$ NMR $\left(300.13 \mathrm{MHz}, \mathrm{CDCl}_{3}\right): \delta 1.59-1.70(\mathrm{~m}$, $1 \mathrm{H}), 1.71-1.86(\mathrm{~m}, 1 \mathrm{H}), 1.87-1.98(\mathrm{~m}, 1 \mathrm{H}), 2.11(\mathrm{~m}, 1 \mathrm{H})$ $2.37-2.56(\mathrm{~m}, 2 \mathrm{H}), 4.56\left(\mathrm{dd},{ }^{3} J_{\mathrm{HH}}=8.9,4.5 \mathrm{~Hz}, 1 \mathrm{H}\right), 6.02$ (br s, $1 \mathrm{H}), 7.08\left(\mathrm{t},{ }^{3} J_{\mathrm{HH}}=8.6 \mathrm{~Hz}, 2 \mathrm{H}\right), 7.29(\mathrm{~m}, 2 \mathrm{H}){ }^{13} \mathrm{C}$ NMR $\left(300.13 \mathrm{MHz}, \mathrm{CDCl}_{3}\right): \delta 19.8\left(\mathrm{CH}_{2}\right), 31.2\left(\mathrm{CH}_{2}\right)$, $32.3\left(\mathrm{CH}_{2}\right), 57.2(\mathrm{CH}), 115.7\left(\mathrm{~d},{ }^{2} j_{\mathrm{CF}}=21.6 \mathrm{~Hz}, 2 \mathrm{CH}\right)$, $127.7\left(\mathrm{~d},{ }^{3} J_{\mathrm{CF}}=8.2 \mathrm{~Hz}, 2 \mathrm{CH}\right), 138.2\left(\mathrm{~d},{ }^{4} J_{\mathrm{CF}}=2.9 \mathrm{~Hz}, \mathrm{C}\right)$, $164.0\left(\mathrm{~d},{ }_{\mathrm{CF}}=246.8 \mathrm{~Hz}, \mathrm{C}\right), 172.2(\mathrm{C})$. HRMS (ESI ${ }^{+}$ $\mathrm{m} / \mathrm{z})$ : calcd for $\left(\mathrm{C}_{11} \mathrm{H}_{12} \mathrm{FNNaO}\right)^{+}(\mathrm{M}+\mathrm{Na})^{+} 216.0795$; found 216.0793

General protocol for the transformation of $\gamma$ - and $\delta$ keto esters 1a-j into optically active lactams using commercially available transaminases. In a $1.5 \mathrm{~mL}$ 
Eppendorf tube, transaminase (2 $\mathrm{mg})$ and the corresponding keto ester $(\mathbf{1 a}-\mathbf{j}, 15$ or $25 \mathrm{mM})$ were added in a phosphate buffer $100 \mathrm{mM} \mathrm{pH} 7.5(500 \mu \mathrm{L}, 1 \mathrm{mM} \mathrm{PLP}$, $1 \mathrm{M}$ isopropylamine), using DMSO $(12.5 \mu \mathrm{L})$ as cosolvent. The reaction was shaken at 30 or $45^{\circ} \mathrm{C}$ and $250 \mathrm{rpm}$ for 24 $\mathrm{h}$ and stopped by the addition of an aqueous $\mathrm{Na}_{2} \mathrm{CO}_{3}$ saturated solution $(200 \mu \mathrm{L})$. Then the mixture was extracted with EtOAc $(2 \times 500 \mu \mathrm{L})$, the organic layers separated by centrifugation ( $2 \mathrm{~min}, 13000 \mathrm{rpm})$, combined and finally dried over $\mathrm{Na}_{2} \mathrm{SO}_{4}$. Conversions into lactams 3a-j were determined by GC and $e e$ values measured by HPLC.

General method for the transformation of $\gamma$ - and $\delta$-keto esters 1a-j into optically active lactams using transaminases overexpressed in $E$. coli. In a $1.5 \mathrm{~mL}$ Eppendorf tube, dry cells of $E$. coli overexpressing the transaminase $(10 \mathrm{mg})$ and $\gamma$-keto ester $(\mathbf{1 a}-\mathbf{j}, 25 \mathrm{mM})$ were added in a phosphate buffer $100 \mathrm{mM}$ pH $7.5(500 \mu \mathrm{L}, 1$ $\mathrm{mM}$ PLP, $1 \mathrm{M}$ isopropylamine) using DMSO (12.5 $\mu \mathrm{L})$ as cosolvent. The reaction was shaken at $30{ }^{\circ} \mathrm{C}$ and $250 \mathrm{rpm}$ for $24 \mathrm{~h}$ and stopped by the addition of an aqueous $\mathrm{Na}_{2} \mathrm{CO}_{3}$ saturated solution $(200 \mu \mathrm{L})$. Then the mixture was extracted with EtOAc $(2 \times 500 \mu \mathrm{L})$, the organic layers separated by centrifugation ( $2 \mathrm{~min}, 13000 \mathrm{rpm}$ ), combined and finally dried over $\mathrm{Na}_{2} \mathrm{SO}_{4}$. Conversions into lactams 3a-j were determined by GC and $e e$ values measured by HPLC.

Preparative biotransformation of $\gamma$-keto esters 1a-c into optically active lactams. In an Erlenmeyer flask, the transaminase (30 mg, ATA-237 for 1a, TA-P1-G06 for 1b or ArS-TA for 1c) and keto ester (1a-c, $30 \mathrm{mg}, 25 \mathrm{mM})$ were added in a phosphate buffer $100 \mathrm{mM} \mathrm{pH} 7.5(1 \mathrm{mM}$ PLP, $1 \mathrm{M}$ isopropylamine) and cosolvent $(2.5 \% \mathrm{v} / \mathrm{v} \mathrm{MeCN}$ for $\mathbf{1 a - b}$ and $2.5 \% \mathrm{v} / \mathrm{v}$ MTBE for $\mathbf{1 c}$ ). The reaction was shaken at $30{ }^{\circ} \mathrm{C}$ and $250 \mathrm{rpm}$ for $24 \mathrm{~h}$ (1a and 1c) or $48 \mathrm{~h}$ (1b) and then stopped by the addition of an aqueous $\mathrm{Na}_{2} \mathrm{CO}_{3}$ saturated solution until $\mathrm{pH}$ 10-11. Then, the mixture was extracted with EtOAc $(5 \times 15 \mathrm{~mL})$, the organic layer separated by centrifugation ( $5 \mathrm{~min}, 4900$ rpm), combined and finally dried over $\mathrm{Na}_{2} \mathrm{SO}_{4}$. The reaction crude was purified by column chromatography ( $\mathrm{MeOH} / \mathrm{CH}_{2} \mathrm{Cl}_{2}$ mixtures), isolating the enantiopure lactams $(S)-3 a, c$ in good yields $(75-89 \%$, respectively).

$(S)$-5-Methylpyrrolidin-2-one $[(S)$-3a $]$ Yellowish solid $\left(19 \mathrm{mg}, 80 \%\right.$ yield). $\mathrm{R}_{\mathrm{f}}\left(5 \% \mathrm{MeOH} / \mathrm{CH}_{2} \mathrm{Cl}_{2}\right)$ : 0.57 . Mp: 43-44 ${ }^{\circ} \mathrm{C}$. IR (NaCl): v 3227, 3054, 2971, 2930, 1694 , $1462,1265 \mathrm{~cm}^{-1} .{ }^{1} \mathrm{H}$ NMR $\left(300.13 \mathrm{MHz}, \mathrm{CDCl}_{3}\right): \delta 1.17(\mathrm{~d}$ $\left.{ }^{3} J_{\mathrm{HH}}=6.3 \mathrm{~Hz}, 3 \mathrm{H}\right), 1.46-1.74(\mathrm{~m}, 1 \mathrm{H}), 2.14-2.25(\mathrm{~m}, 1 \mathrm{H})$, $2.25-2.34(\mathrm{~m}, 2 \mathrm{H}), 3.56-3.90(\mathrm{~m}, 1 \mathrm{H}), 7.37(\mathrm{~s}, 1 \mathrm{H}) .{ }^{13} \mathrm{C}$ NMR (300.13 MHz, $\left.\mathrm{CDCl}_{3}\right): \delta 19.8\left(\mathrm{CH}_{2}\right), 22.7\left(\mathrm{CH}_{3}\right)$, $30.4\left(\mathrm{CH}_{2}\right), 30.9\left(\mathrm{CH}_{2}\right), 48.7(\mathrm{CH}), 172.5(\mathrm{C})$. HRMS $\left(\mathrm{ESI}^{+}, \mathrm{m} / \mathrm{z}\right)$ : calcd for for $\left(\mathrm{C}_{5} \mathrm{H}_{9} \mathrm{NNaO}\right)^{+}(\mathrm{M}+\mathrm{Na})^{+}$ 122.0576; found 122.0574

$(S)$-6-Methylpiperidin-2-one $[(S)-3 c]$ : White solid $(19$ $\mathrm{mg}$, $89 \%$ yield). $\mathrm{R}_{\mathrm{f}}\left(5 \% \mathrm{MeOH} / \mathrm{CH}_{2} \mathrm{Cl}_{2}\right): 0.51$. Mp: 87$88^{\circ} \mathrm{C}$. IR ( $\left.\mathrm{NaCl}\right): v \mathrm{3} 392,3054,2972,2935,1659,1468$, $1265 \mathrm{~cm}^{-1} .{ }^{1} \mathrm{H}$ NMR $\left(300.13 \mathrm{MHz}, \mathrm{CDCl}_{3}\right): \delta 1.18\left(\mathrm{~d},{ }^{3} J_{\mathrm{HH}}\right.$ $=6.4 \mathrm{~Hz}, 3 \mathrm{H}), 1.26-1.36(\mathrm{~m}, 1 \mathrm{H}), 1.52-1.79(\mathrm{~m}, 1 \mathrm{H}), 1.75-$ $1.98(\mathrm{~m}, 2 \mathrm{H}), 2.09-2.45(\mathrm{~m}, 2 \mathrm{H}), 3.44-3.55(\mathrm{~m}, 1 \mathrm{H}), 6.69$ (s, 1H). ${ }^{13} \mathrm{C}$ NMR $\left(300.13 \mathrm{MHz}, \mathrm{CDCl}_{3}\right): \delta 22.1\left(\mathrm{CH}_{3}\right)$, $29.0\left(\mathrm{CH}_{2}\right), 30.7\left(\mathrm{CH}_{2}\right), 50.2(\mathrm{CH}), 178.7$ (C). HRMS $\left(\mathrm{ESI}^{+}, \mathrm{m} / \mathrm{z}\right)$ : calcd for $\left(\mathrm{C}_{6} \mathrm{H}_{11} \mathrm{NNaO}\right)^{+}(\mathrm{M}+\mathrm{Na})^{+} 136.0732$; found 136.0730

Preparative biotransformation of $\gamma$-keto esters $1 \mathrm{~d}$ and $1 \mathrm{e}$ and $\delta$-keto esters $1 \mathrm{i}$ and $1 \mathrm{j}$ into optically active lactams. In an Erlenmeyer flask, the TA (30 mg, ATA-303 for keto ester 1d, ATA-025 for keto ester 1e and ATA-237 for keto esters $\mathbf{1 i}$ and $\mathbf{1 j}$ ) and keto ester $(\mathbf{1 d}, \mathbf{1 e}, \mathbf{1 i}$ and $\mathbf{1 j}$, $30 \mathrm{mg}, 15 \mathrm{mM}$ ) were added in phosphate buffer $100 \mathrm{mM}$ $\mathrm{pH} 7.5$ ( $1 \mathrm{mM}$ PLP, 0.1 or $1 \mathrm{M}$ isopropylamine $)$ and MeCN $(2.5 \% \mathrm{v} / \mathrm{v})$. The reaction was shaken at $45{ }^{\circ} \mathrm{C}$ and $250 \mathrm{rpm}$ for $24 \mathrm{~h}(\mathbf{1 d}, \mathbf{1 i}$ and $\mathbf{1 j})$ or $48 \mathrm{~h}(\mathbf{1 e})$ and then stopped by adding an aqueous saturated solution of $\mathrm{Na}_{2} \mathrm{CO}_{3}$ until pH 10-11. Then the mixture was extracted with ethyl acetate $(5 \times 15 \mathrm{~mL})$, the organic layer separated by centrifugation ( $5 \mathrm{~min}, 4900 \mathrm{rpm})$, combined and finally dried over $\mathrm{Na}_{2} \mathrm{SO}_{4}$. The reaction crude was purified by column chromatography $\left(\mathrm{MeOH} / \mathrm{CH}_{2} \mathrm{Cl}_{2}\right.$ mixtures), yielding the lactams $(R)-\mathbf{3 d}$ and $\mathbf{3 e}$ and $(S)-\mathbf{3 i}$ and $\mathbf{3 j}$ in moderate to good yields $(66-90 \%)$ and good to excellent enantiomeric excess (91->99\%).

Preparative biotransformation of $\boldsymbol{\gamma}$-keto esters 1f-h into optically active lactams. In an Erlenmeyer flask, ATA$025(100 \mathrm{mg})$ and keto ester (1f-h, $100 \mathrm{mg}, 15 \mathrm{mM})$ were added in phosphate buffer $100 \mathrm{mM} \mathrm{pH} 7.5$ (1 mM PLP, 0.1 or $1 \mathrm{M}$ isopropylamine) and $\mathrm{MeCN}(2.5 \% \mathrm{v} / \mathrm{v})$. The reaction was shaken at $45^{\circ} \mathrm{C}$ for $48 \mathrm{~h}$ and then stopped by adding a saturated solution of $\mathrm{Na}_{2} \mathrm{CO}_{3}$ until $\mathrm{pH} 10-11$. Then, the mixture was extracted with ethyl acetate $(5 \times 15$ $\mathrm{mL}$ ), the organic layer separated by centrifugation ( $5 \mathrm{~min}$, $4900 \mathrm{rpm})$, combined and finally dried over $\mathrm{Na}_{2} \mathrm{SO}_{4}$. The reaction crude was purified by column chromatography $\left(\mathrm{MeOH} / \mathrm{CH}_{2} \mathrm{Cl}_{2}\right.$ mixtures), yielding lactams $(R)-\mathbf{3 f}-\mathbf{h}$ in good yields $(75-86 \%)$ and excellent enantiomeric excess $(>99 \%)$. Optical rotation values for $(R)$-lactams $\mathbf{3 f}-\mathbf{h}$ $[\alpha]_{\mathrm{D}_{25}}^{25}=+24.5(\mathrm{c}=1.0, \mathrm{EtOH})$ for $(R)-\mathbf{3 f}$ in $>99 \%$ ee $\alpha]_{\mathrm{D}_{25}}=+21.1(\mathrm{c}=1.0, \mathrm{EtOH})$ for $(R)-\mathbf{3 g}$ in $>99 \% e e$; $[\alpha]_{\mathrm{D}}^{25}=+44.1(\mathrm{c}=1.0, \mathrm{EtOH})$ for $(R)-3 \mathbf{h}$ in $>99 \% e e$.

\section{Acknowledgements}

Financial support from the Spanish Ministry of Economy and Competitiveness (MEC, Projects CTQ2013-44153-P and CTQ2016-75752-R) and the Government of the Principado de Asturias (Project FC-15-GRUPIN14-002) is gratefully acknowledged. A.M.-I thanks MEC for a predoctoral fellowship inside the FPI program, while L.A.Z thanks the national Brazilian agency CAPES for a postdoctoral fellowship.

\section{References}

[1] M. A. Ogliaruso, J. F. Wolfe, Synthesis of Lactones and Lactams, John Wiley \& Sons, Inc., West Sussex, 1993.

[2] a) C. R. Pitts, T. Lectka, Chem. Rev. 2014, 114, 79307953; b) G. S. Singh, S. Sudheesh, Arkivoc 2014, $i$, 227-385; c) Y. Kumar, P. Singh, G. Bhargava, RSC Adv. 2016, 6, 99220-99250.

[3] a) L.-W. Ye, C. Shu, F. Gagosz, Org. Biomol. Chem. 2014, 12, 1833-1845; b) J. Caruano, G. G. Muccioli, R. Robiette, Org. Biomol. Chem. 2016, 14, 10134-10156.

[4] J. Albarrán-Velo, D. González-Martínez, V. GotorFernández, Biocatal. Biotransf. 2018, 36, 112-140.

[5] E. Busto, V. Gotor-Fernández, V. Gotor, Chem. Rev. 2011, 111, 3998-4035.

[6] See, for instance: a) A. L. Gutman, E. Meyer, X. Yue, C. Abell, Tetrahedron Lett. 1992, 33, 3943-3946; b) E. Stavila, K. Loos, Tetrahedron Lett. 2013, 54, 370-372; c) C.-J. Aurell, S. Karlsson, F. Pontén, S. M. Andersen, Org. Process Res. Devel. 2014, 18, 1116-1119.

[7] a) D. Koszelewski, D. Clay, K. Faber, W. Kroutil, J. Mol. Catal. B: Enzym. 2009, 60, 191-194; b) M. D. Truppo, J. D. Rozzell, N. J. Turner, Org. Process Res. Devel. 2010, 14, 234-237; c) C. K. Chung, P. G. Bulger, B. Kosjek, K. M. Belyk, N. Rivera, M. E. Scott, G. R. Humphrey, J. Limanto, D. C. Bachert, K. M. Emerson, Org. Process Res. Devel. 2014, 18, 215-227. 
[8] G. A. Aleku, S. P. France, H. Man, J. Mangas-Sanchez, S. L. Montgomery, M. Sharma, F. Leipold, S. Hussain, G. Grogan, N. J. Turner, Nat. Chem. 2017, 9, 961-969.

[9] a) A. S. Touchy, S. M. A. Hakim Siddiki, K. Kon, K.-i. Shimizu, ACS Catal. 2014, 4, 3045-3050; b) J. D. Vidal, M. J. Climent, P. Concepcion, A. Corma, S. Iborra, M. J. Sabater, ACS Catal. 2015, 5, 5812-5821.

[10] C. E. Paul, M. Rodríguez-Mata, E. Busto, I. Lavandera, V. Gotor-Fernández, V. Gotor, S. GarcíaCerrada, J. Mendiola, O. de Frutos, I. Collado, Org. Process Res. Devel. 2014, 18, 788-792.

[11] U. Kaulman, K. Smithies, M. E. B. Smith, H. C. Hailes, J. M. Ward, Enzyme Microb. Technol. 2007, 41, 628-637.

[12] S. Pannuri, S. V. Kamat, A. R. M. Garcia, WO 2006/063336 A2 20060615, Cambrex North Brunswick Inc., 2006.

[13] a) Y. Yamada, A. Iwasaki, N. Kizaki, K. Matsumoto, Y. Ikenaka, M. Ogura, J. Hasegawa, (Kaneka Corporation), PCT Int. Appl. WO 9848030A1 19981029, 1998; b) A. Iwasaki, Y. Yamada, N. Kizaki, Y. Ikenaka, J. Hasegawa, Appl. Microbiol. Biotechnol. 2006, 69, 499-505; c) F. G. Mutti, C. S. Fuchs, D. Pressnitz, J. H. Sattler, W. Kroutil, Adv. Synth. Catal. 2011, 353, 3227-3233.

[14] C. K. Savile, J. M. Janey, E. M. Mundorff, J. C. Moore, S. Tam, W. R. Jarvis, J. C. Colbeck, A. Krebber, F. J. Fleitz, J. Brands, P. N. Devine, G. W. Huisman, G. J. Georges, Science 2010, 329, 305-309.
[15] F. Guo, P. Berglund, Green Chem. 2017, 19, 333360.

[16] $(S)-5$-Methylpyrrolidin-2-one $(\mathbf{3 a}):[\alpha]_{\mathrm{D}}{ }^{25}=-10.0$ (c $=1.0, \mathrm{EtOH})$. Described in the literature: $[\alpha]_{\mathrm{D}}{ }^{25}=-21.3$ (c $=0.9$, water) for the $(S)$-enantiomer. J. M. García, M. A. Maestro, M. Oiarbide, J. M. Odriozola, J. Razkin, C. Palomo, Org. Lett. 2009, 11, 3826-3829.

[17] $(S)-6-M e t h y l p i p e r i d i n-2-o n e(3 c):[\alpha]_{\mathrm{D}}^{22}=+23.7(\mathrm{c}=$ 1.0, EtOH). Described in the literature: $[\alpha]_{\mathrm{D}}{ }^{20}=-24.0$ (c $=0.4, \mathrm{CH}_{2} \mathrm{Cl}_{2}$ ) for the $(R)$-enantiomer. M. Amat, N. Llor, J. Hidalgo, C. Escolano, J. Bosch, J. Org. Chem. 2003, 68, 1919-1928.

[18] $(R)$-5-Phenylpyrrolidin-2-one $(3 \mathbf{d}):[\alpha]_{\mathrm{D}}{ }^{20}=+42.2(\mathrm{c}$ $=1.0, \mathrm{EtOH})$. Described in the literature: $[\alpha]_{\mathrm{D}}{ }^{20}=+41.0$ (c $=0.4, \mathrm{CH}_{2} \mathrm{Cl}_{2}$ ) for the $(R)$-enantiomer. M. N. Cheemala, P. Knochel, Org. Lett. 2007, 9, 3089-3092.

[19] $(R)-5-(4-M e t h o x y p h e n y l) p y r r o l i d i n-2-o n e ~(3 e):[\alpha]_{\mathrm{D}}{ }^{20}$ $=+28.1(\mathrm{c}=1.0, \mathrm{EtOH})$. Described in the literature: $[\alpha]_{\mathrm{D}}{ }^{20}=+40.5\left(\mathrm{c}=0.7, \mathrm{CH}_{2} \mathrm{Cl}_{2}\right)$ for the $(R)$-enantiomer. D. Guijarro, O. Pablo, M. Yus, J. Org. Chem. 2013, 78, 3647-3654.

[20] $(S)-6$-Phenylpiperidin-2-one $(3 \mathbf{i}):[\alpha]_{\mathrm{D}}{ }^{20}=-48.6(\mathrm{c}=$ 1.0, EtOH). Described in the literature: $[\alpha]_{\mathrm{D}}{ }^{20}=-58.0$ $\left(\mathrm{c}=0.54, \mathrm{CHCl}_{3}\right)$ for the $(S)$-enantiomer. $(S)-6-(4-$ Fluorophenyl)piperidin-2-one $(\mathbf{3 j}):[\alpha]_{\mathrm{D}}{ }^{20}=-35.4(\mathrm{c}=$ $0.6, \mathrm{EtOH})$. Described in the literature: $[\alpha]_{\mathrm{D}}{ }^{20}=-47.2$ (c $=0.60, \mathrm{CHCl}_{3}$ ) for the $(S)$-enantiomer. R. Sallio, S. Lebrun, F. Agbossou-Niedercorn, C. Michon, E. Deniau, Tetrahedron: Asymmetry 2012, 23, 998-1004. 


\section{FULL PAPER}

Conversion of $\gamma$ - and $\delta$-Keto Esters into Optically

Active Lactams. Transaminases in Cascade

Processes

Adv. Synth. Catal. Year, Volume, Page - Page

Ángela Mourelle-Insua, Luiz Arthur Zampieri, Iván Lavandera* and Vicente Gotor-Fernández*

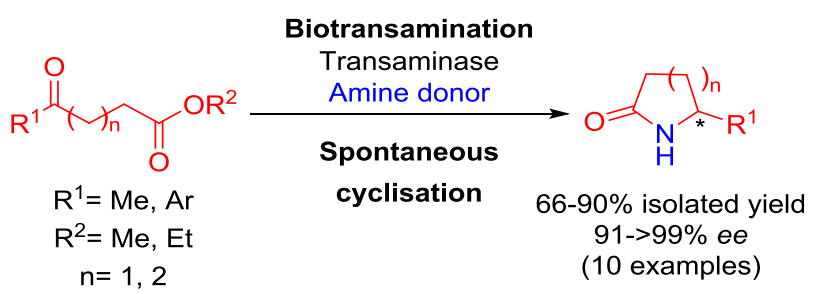

